\title{
Ultrasound-Promoted Chemoselective Oxysulfonylation of Alkenes
}

\author{
Queila P. S. B. Freitas, ${ }^{a}$ Raffael A. G. Lira, ${ }^{a}$ Jucleiton J. R. Freitas, ${ }^{a}$ Gilson Zeni ${ }^{b}$ and \\ Paulo H. Menezes*,a \\ ${ }^{a}$ Departamento de Química Fundamental, Universidade Federal de Pernambuco, \\ Av. Prof. Moraes Rego, s/n, 50670-901 Recife-PE, Brazil \\ ${ }^{b}$ Departamento de Química, Universidade Federal de Santa Maria, Av. Roraima, 1000, \\ 97105-900 Santa Maria-RS, Brazil
}

\begin{abstract}
The ultrasound-assisted oxysulfonylation of different alkenes using sodium salts of organosulfinic acids under air atmosphere is described. The reaction is chemo- and regioselective and the corresponding $\beta$-keto-sulfones were obtained in good yields as major products. The use of ultrasound greatly accelerated the formation of products when compared to the conventional methods.
\end{abstract}

Keywords: ultrasound, oxysulfonylation, iron trichloride, $\beta$-keto-sulfones

\section{Introduction}

The synthesis of organosulfur compounds experienced a tremendous growth in the last years. ${ }^{1}$ This is particularly true for $\beta$-keto-sulfones due to their applications in the synthesis of natural products ${ }^{2}$ and heterocyclic compounds ${ }^{3}$ as well as to their biological properties. ${ }^{4}$ These qualities led to the emergence of several methods for the synthesis of these compounds and strategies based on the oxidation of $\beta$-keto-sulfides, ${ }^{5}$ alkylation using $\alpha$-halo-ketones, ${ }^{6}$ acylation of methyl sulfones ${ }^{7}$ and sulfonylation of methyl ketones ${ }^{8}$ using a variety of substrates were described. However, most of them have some limitations such as being non-catalytic, involving multi-step synthesis of the starting materials, or the use of harsh conditions to promote the reaction.

The oxysulfonylation of alkenes or alkynes appeared as an easy alternative for the synthesis of $\beta$-keto-sulfones. The oxysulfonylation is based on the reaction of alkenes or alkynes with sulfonyl radicals. These radicals can be generated from readily available starting materials, being sulfonyl halides, ${ }^{9}$ sulfonylhydrazides, ${ }^{10,11}$ or the oxidation of sulfonates, ${ }^{12}$ the most commonly used due to the high atomic efficiency. ${ }^{13,14}$ Despite these characteristics, all these methods require long reaction times, heating and/or the use of a variety of additives to promote the reaction effectively. Accordingly, the development of a simpler method that could

*e-mail: paulo.menezes@pq.cnpq.br make the oxysulfonylation reaction more efficient in terms of yield and reaction time would be of the great interest.

Lei and co-workers ${ }^{15}$ described the generation of sulfonyl radicals from sulfinic acids in the presence of pyridine and dioxygen for the synthesis of $\beta$-hydroxysulfones. It is also well-known that the activation of dioxygen mostly proceeded by a radical process. ${ }^{16}$

Within this context, the use of ultrasound as a source of hydroxyl radical and other reactive oxygen species through the formation, growth and implosive collapse of microbubbles in a liquid could result in an unusual reaction environment within and in the vicinity of bubbles. ${ }^{17}$ These characteristics make the use of ultrasound irradiation a common partner in a variety of areas such as organic and organometallic chemistry, materials science, aerogels, food chemistry and medicinal research. ${ }^{18,19}$

In addition, the use of ultrasound is in accordance to the principles of sustainable chemistry, while the demand for methods based on the use of less hazardous chemicals and/or solvents, and the reduction of used energy is an expanding area. ${ }^{20}$

\section{Experimental}

\section{General methods}

All reagents and solvents used were previously purified and dried in agreement with the literature. ${ }^{21} \mathrm{FeCl}_{3}(97 \%)$, 
alkenes $\mathbf{1 a - g}, \mathbf{1 i}, \mathbf{1} \mathbf{j}$ and $\mathbf{1} \mathbf{l}$ and sodium sulfinates, $\mathbf{2 a - d}$, were purchased from Aldrich Chemical Co. and used as received. Reactions were monitored by thin-layer chromatography (TLC) on $0.25 \mathrm{~mm}$ E. Merck silica gel 60 plates (F254) using UV light, vanillin and $p$-anisaldehyde as visualizing agents. ${ }^{1} \mathrm{H}$ and ${ }^{13} \mathrm{C}$ nuclear magnetic resonance (NMR) data were recorded in $\mathrm{CDCl}_{3}$. The chemical shifts are reported as delta $(\delta)$ units in parts per million $(\mathrm{ppm})$ relative to the solvent residual peak as the internal reference. ${ }^{11} \mathrm{~B}$ NMR spectrum $(128 \mathrm{MHz})$ was obtained in $\mathrm{CDCl}_{3}$. Spectrum was calibrated using $\mathrm{BF}_{3} \cdot \mathrm{Et}_{2} \mathrm{O}(0.0 \mathrm{ppm})$ as external reference. ${ }^{22}$ Coupling constants $(J)$ for all spectra are reported in hertz $(\mathrm{Hz})$. The sonication was performed in an 8890E-DTH ultrasonic cleaner (with a frequency of $47 \mathrm{kHz}$ and a nominal power $35 \mathrm{~W}$; Cole Parmer Co.). The reaction flask was located at the maximum energy area in the cleaner, the surface of reactants was slightly lower than the level of the water. The reaction temperature was controlled by water bath.

General procedure for the synthesis of $\beta$-keto-sulfones $(3 a-0)$

In a $25 \mathrm{~mL}$ round-bottomed flask containing $\mathrm{FeCl}_{3}$ $(0.05 \mathrm{mmol}, 8.2 \mathrm{mg})$ in a 2:1 mixture of $\mathrm{MeCN}_{\mathrm{H}} \mathrm{H}_{2} \mathrm{O}(3 \mathrm{~mL})$, it was added the appropriate sodium sulfinate $(1.5 \mathrm{mmol})$, alkene $(0.25 \mathrm{mmol})$ and $\left(\mathrm{NH}_{4}\right)_{2} \mathrm{~S}_{2} \mathrm{O}_{8}(0.05 \mathrm{mmol}, 11.5 \mathrm{mg})$. The mixture was placed on an ultrasound bath and irradiated for $1 \mathrm{~h}$.

After this period, the mixture was diluted with $\mathrm{CH}_{2} \mathrm{Cl}_{2}$ $(5 \mathrm{~mL})$ and washed with $\mathrm{H}_{2} \mathrm{O}(3 \times 15 \mathrm{~mL})$. The organic phase was dried under anhydrous $\mathrm{MgSO}_{4}$, filtered and the solvent removed in vacuo. The residue was purified by silica gel chromatographic column [hexanes:EtOAc (8:2)] to yield the corresponding products.

\section{1-Phenyl-2-(phenylsulfonyl)ethanone (3a)}

Obtained $53.4 \mathrm{mg}(82 \%)$; ${ }^{1} \mathrm{H} \mathrm{NMR}\left(400 \mathrm{MHz}, \mathrm{CDCl}_{3}\right.$ ) $\delta 7.93\left(\mathrm{~d}, J 8.2 \mathrm{~Hz}, 2 \mathrm{H}, \mathrm{H}_{\text {Aryl }}\right), 7.89(\mathrm{~d}, J 8.2 \mathrm{~Hz}, 2 \mathrm{H}$, $\left.\mathrm{H}_{\text {Aryl }}\right), 7.68-7.89(\mathrm{~m}, 2 \mathrm{H}), 7.54\left(\mathrm{t}, J 7.4 \mathrm{~Hz}, 2 \mathrm{H}, \mathrm{H}_{\text {Ary }}\right), 7.47$ (t, $\left.J 7.4 \mathrm{~Hz}, 2 \mathrm{H}, \mathrm{H}_{\text {Aryl }}\right), 4.74\left(\mathrm{~s}, 2 \mathrm{H},-\mathrm{CH}_{2}-\right) ;{ }^{13} \mathrm{C}$ NMR $\left(100 \mathrm{MHz}, \mathrm{CDCl}_{3}\right) \delta 187.9,138.7,135.7,134.3,134.2$, $129.25,129.17,128.8,128.5,63.4$. The data match with the previously described compound. ${ }^{23}$

1-(Naphthalen-2-yl)-2-(phenylsulfonyl)ethanone (3b)

Obtained $48.9 \mathrm{mg}(63 \%) ;{ }^{1} \mathrm{H}$ NMR $\left(300 \mathrm{MHz}, \mathrm{CDCl}_{3}\right)$ $\delta 8.48\left(\mathrm{~s}, 1 \mathrm{H}, \mathrm{H}_{\text {Aryl }}\right), 7.99-7.87\left(\mathrm{~m}, 6 \mathrm{H}, \mathrm{H}_{\text {Aryl }}\right), 7.68-7.52$ $\left(\mathrm{m}, 5 \mathrm{H}, \mathrm{H}_{\text {Aryl }}\right), 4.87\left(\mathrm{~s}, 2 \mathrm{H},-\mathrm{CH}_{2}-\right) ;{ }^{13} \mathrm{C}$ NMR $(75 \mathrm{MHz}$, $\left.\mathrm{CDCl}_{3}\right) \delta 187.9,138.7,136.1,134.3,133.1,132.3,132.2$, $130.0,129.4,129.2,128.9,128.6,127.8,127.2,123.9,63.7$. The data match with the previously described compound. ${ }^{23}$
2-Phenyl-1-(phenylsulfonyl)propan-2-ol (4c)

Obtained 62.2 mg (90\%); ${ }^{1} \mathrm{H}$ NMR $\left(300 \mathrm{MHz}, \mathrm{CDCl}_{3}\right)$ $\delta 7.59\left(\mathrm{~d}, J 7.0 \mathrm{~Hz}, 2 \mathrm{H}, \mathrm{H}_{\text {Aryl }}\right), 7.52\left(\mathrm{t}, J 7.0 \mathrm{~Hz}, 1 \mathrm{H}, \mathrm{H}_{\text {Ary }}\right)$, 7.38 (t, $\left.J 7.6 \mathrm{~Hz}, 2 \mathrm{H}, \mathrm{H}_{\text {Ary }}\right), 7.30-7.27\left(\mathrm{~m}, 2 \mathrm{H}, \mathrm{H}_{\text {Ary }}\right)$, 7.21-7.16 (m, $\left.3 \mathrm{H}, \mathrm{H}_{\text {Ary }}\right), 4.61(\mathrm{~s}, 1 \mathrm{H},-\mathrm{OH}), 3.75(\mathrm{~d}$, $\left.J 14.6 \mathrm{~Hz}, 1 \mathrm{H},-\mathrm{CH}_{2}-\right), 3.62\left(\mathrm{~d}, J 14.6 \mathrm{~Hz}, 1 \mathrm{H},-\mathrm{CH}_{2}-\right), 1.71$ (s, $\left.3 \mathrm{H},-\mathrm{CH}_{3}\right) ;{ }^{13} \mathrm{C}$ NMR $\left(75 \mathrm{MHz}, \mathrm{CDCl}_{3}\right) \delta 144.3,140.2$, 133.4, 129.0, 128.2, 127.4, 127.2, 124.6, 73.1, 66.6, 30.7. The data match with the previously described compound. ${ }^{24}$

1-(4-Fluorophenyl)-2-(phenylsulfonyl)ethanone (3e)

Obtained $46.6 \mathrm{mg}(67 \%) ;{ }^{1} \mathrm{H}$ NMR $\left(400 \mathrm{MHz}, \mathrm{CDCl}_{3}\right)$ $\delta$ 8.02-7.98 (m, $\left.4 \mathrm{H}, \mathrm{H}_{\text {Aryl }}\right), 7.89\left(\mathrm{~d}, J 7.6 \mathrm{~Hz}, 2 \mathrm{H}, \mathrm{H}_{\text {Ary }}\right)$, $7.69\left(\mathrm{t}, J 7.8 \mathrm{~Hz}, 2 \mathrm{H}, \mathrm{H}_{\text {Aryl }}\right), 7.56\left(\mathrm{t}, J 7.8 \mathrm{~Hz}, 2 \mathrm{H}, \mathrm{H}_{\text {Ary }}\right)$, $7.17\left(\mathrm{t}, J 8.6 \mathrm{~Hz}, 2 \mathrm{H}, \mathrm{H}_{\text {Aryl }}\right), 4.71\left(\mathrm{~s}, 2 \mathrm{H},-\mathrm{CH}_{2}-\right) ;{ }^{13} \mathrm{C} \mathrm{NMR}$ $\left(100 \mathrm{MHz}, \mathrm{CDCl}_{3}\right) \delta 186.3,166.5(\mathrm{~d}, J 256.5 \mathrm{~Hz}), 165.2$, $138.6,134.2,132.2,129.2,128.5,116.2,116.0,63.6$. The data match with the previously described compound. ${ }^{23}$

1-(4-Methoxyphenyl)-2-(phenylsulfonyl)ethanone (3f)

Obtained $37.7 \mathrm{mg}(52 \%) ;{ }^{1} \mathrm{H} \mathrm{NMR}\left(400 \mathrm{MHz}, \mathrm{CDCl}_{3}\right)$ $\delta$ 7.94-7.88 (m, 4H, $\left.\mathrm{H}_{\text {Aryl }}\right), 7.67\left(\mathrm{t}, J 7.2 \mathrm{~Hz}, 2 \mathrm{H}, \mathrm{H}_{\text {Ary }}\right), 7.55$ $\left(\mathrm{t}, J 7.4 \mathrm{~Hz}, 2 \mathrm{H}, \mathrm{H}_{\text {Aryl }}\right), 6.95\left(\mathrm{~d}, J 8.2 \mathrm{~Hz}, 2 \mathrm{H}, \mathrm{H}_{\text {Ary }}\right), 4.69$ (s, $\left.2 \mathrm{H},-\mathrm{CH}_{2}-\right), 3.89\left(\mathrm{~s}, 3 \mathrm{H}, \mathrm{OCH}_{3}\right) ;{ }^{13} \mathrm{C}$ NMR $(100 \mathrm{MHz}$, $\left.\mathrm{CDCl}_{3}\right) \delta 186.1,164.5,138.7,134.1,131.8,129.1,128.8$, $128.5,114.1,63.5,55.6$. The data match with the previously described compound. ${ }^{23}$

1-(4-Methoxyphenyl)-2-(phenylsulfonyl)ethanol (4f)

Obtained $18.3 \mathrm{mg}(25 \%) ;{ }^{1} \mathrm{H} \mathrm{NMR}\left(300 \mathrm{MHz}, \mathrm{CDCl}_{3}\right)$ $\delta 7.95\left(\mathrm{~d}, J 7.6 \mathrm{~Hz}, 2 \mathrm{H}, \mathrm{H}_{\text {Ary }}\right), 7.71-7.68\left(\mathrm{~m}, 1 \mathrm{H}, \mathrm{H}_{\text {Ary }}\right)$, 7.61-7.56 (m, 2H, $\left.\mathrm{H}_{\text {Ary }}\right), 7.20\left(\mathrm{~d}, J 8.8 \mathrm{~Hz}, 2 \mathrm{H}, \mathrm{H}_{\text {Ary }}\right), 6.83$ $\left(\mathrm{d}, J 8.8 \mathrm{~Hz}, 2 \mathrm{H}, \mathrm{H}_{\text {Aryl }}\right), 5.24-5.20(\mathrm{~m}, 1 \mathrm{H},-\mathrm{CH}(\mathrm{OH})-)$, $3.77\left(\mathrm{~s}, 3 \mathrm{H},-\mathrm{OCH}_{3}\right), 3.60(\mathrm{~d}, J 8.8 \mathrm{~Hz}, 1 \mathrm{H}, \mathrm{OH}), 3.51(\mathrm{dd}$, $\left.J 14.7,10.0 \mathrm{~Hz}, 1 \mathrm{H},-\mathrm{CH}_{2}-\right), 3.32(\mathrm{dd}, J 14.7,1.8 \mathrm{~Hz}$, $\left.1 \mathrm{H},-\mathrm{CH}_{2}-\right) ;{ }^{13} \mathrm{C}$ NMR $\left(75 \mathrm{MHz}, \mathrm{CDCl}_{3}\right) \delta 159.5,139.2$, 134.0, 132.8, 129.4, 127.9, 126.9, 114.1, 68.0, 63.9, 55.3. The data match with the previously described compound. ${ }^{24}$

1-(4-Aminophenyl)-2-(phenylsulfonyl)ethanol (4g)

Obtained $62 \mathrm{mg}(89 \%) ;{ }^{1} \mathrm{H}$ NMR $\left(400 \mathrm{MHz}, \mathrm{CDCl}_{3}\right) \delta$ $7.95(\mathrm{~d}, 2 \mathrm{H}, J 7.8 \mathrm{~Hz}), 7.68$ (t, 1H, J 7.4 Hz), $7.58(\mathrm{~d}, 2 \mathrm{H}$, $J 7.4 \mathrm{~Hz}), 7.06(\mathrm{~d}, 2 \mathrm{H}, J 8.2 \mathrm{~Hz}), 6.61(\mathrm{~d}, 2 \mathrm{H}, J 8.2 \mathrm{~Hz})$, $5.15(\mathrm{~m}, 1 \mathrm{H}), 3.51(\mathrm{dd}, 1 \mathrm{H}, J 9.8$ and $4.3 \mathrm{~Hz}), 3.31(\mathrm{dd}$, $1 \mathrm{H}, J 14$ and $2 \mathrm{~Hz}) ;{ }^{13} \mathrm{C} \mathrm{NMR}\left(100 \mathrm{MHz}, \mathrm{CDCl}_{3}\right) \delta 146.6$, 139.3, 133.9, 130.5, 129.3, 127.9, 126.9, 115.1, 68.2, 63.8 .

\section{1-Phenyl-2-( $p$-tolylsulfonyl)ethanone (3m)}

Obtained $48.0 \mathrm{mg}(70 \%) ;{ }^{1} \mathrm{H}$ NMR $\left(400 \mathrm{MHz}, \mathrm{CDCl}_{3}\right)$ $\delta 7.95\left(\mathrm{~d}, J 7.8 \mathrm{~Hz}, 2 \mathrm{H}, \mathrm{H}_{\text {Aryl }}\right), 7.77\left(\mathrm{~d}, J 8.3 \mathrm{~Hz}, 2 \mathrm{H}, \mathrm{H}_{\text {Aryl }}\right)$, $7.63\left(\mathrm{t}, J 7.8 \mathrm{~Hz}, 1 \mathrm{H}, \mathrm{H}_{\text {Aryl }}\right), 7.49$ (t, $\left.J 7.8 \mathrm{~Hz}, 2 \mathrm{H}, \mathrm{H}_{\text {Aryl }}\right)$, 
$7.34\left(\mathrm{~d}, J 8.3 \mathrm{~Hz}, 2 \mathrm{H}, \mathrm{H}_{\text {Aryl }}\right), 4.72\left(\mathrm{~s}, 2 \mathrm{H},-\mathrm{CH}_{2}-\right), 2.45$ (s, $\left.3 \mathrm{H},-\mathrm{CH}_{3}\right) ;{ }^{13} \mathrm{C}$ NMR $\left(100 \mathrm{MHz}, \mathrm{CDCl}_{3}\right) \delta 188.1,145.3$, $135.8,134.3,129.8,129.3,128.8,128.6,63.8,21.7$. The data match with the previously described compound. ${ }^{23}$

1-Phenyl-2-(methylsulfonyl)ethanone (3n)

Obtained $19.8 \mathrm{mg}(40 \%) ;{ }^{1} \mathrm{H} \mathrm{NMR}\left(300 \mathrm{MHz}, \mathrm{CDCl}_{3}\right)$ $\delta 8.01\left(\mathrm{~d}, J 7.6 \mathrm{~Hz}, 2 \mathrm{H}, \mathrm{H}_{\text {Aryl }}\right), 7.67\left(\mathrm{t}, J 7.6 \mathrm{~Hz}, 1 \mathrm{H}, \mathrm{H}_{\text {Aryl }}\right)$, $7.53\left(\mathrm{t}, J 7.0 \mathrm{~Hz}, 2 \mathrm{H}, \mathrm{H}_{\text {Ary }}\right), 4.61\left(\mathrm{~s}, 2 \mathrm{H},-\mathrm{CH}_{2}-\right), 3.16$ (s, $\left.3 \mathrm{H},-\mathrm{CH}_{3}\right) ;{ }^{13} \mathrm{C}$ NMR $\left(75 \mathrm{MHz}, \mathrm{CDCl}_{3}\right) \delta 189.2,135.6$, $134.7,129.2,129.0,61.2,41.8$. The data match with the previously described compound. ${ }^{23}$

\section{Results and Discussion}

This work describes the use of ultrasound irradiation for the chemo- and regioselective synthesis of $\beta$-ketosulfones based on the type reaction of alkenes and sodium salts of organosulfinic acids. In the course of developing milder reaction conditions, the effect of the solvent to promote the reaction was first examined. Thus, styrene, 1a $(0.25 \mathrm{mmol})$, and benzenesulfinic acid sodium salt, 2a $(0.375 \mathrm{mmol})$, were used as model compounds and treated at room temperature with $\mathrm{FeCl}_{3}(20 \mathrm{~mol} \%)$ using different solvents. The progress of the reaction was monitored by TLC and the results are depicted in Table 1.

From Table 1, it can be observed that mixtures of the corresponding $\beta$-keto-sulfone (3a) and $\beta$-hydroxy-sulfone (4a) were obtained in all cases with ratios depending on the type of solvent. When dichloromethane was used, a good conversion from 1a to the products and a lower selectivity to the desired compound 3a were observed (Table 1, entry 1). When water or tetrahydrofuran (THF) were used, lower conversions were also observed in both cases, probably due to the low solubility of starting materials in these solvents (Table 1, entries 2 and 3). Better results were observed when acetone or acetonitrile were used after $24 \mathrm{~h}$ of reaction (Table 1, entries 4 and 5). A dramatic effect occurred when the reaction was performed under sonication (Table 1, entries 6 to 8). When acetone or acetonitrile were used as the reaction solvent, an increment in both conversion and selectivity was observed, however, when a 2:1 mixture of acetonitrile and water was used, $\mathbf{3 a}$ was obtained in better conversions and selectivities (Table 1, entry 8 ). The most evident effect of the use of ultrasound in the reaction was the reduction of the time from $24 \mathrm{~h}$ to only $1 \mathrm{~h}$.

Next, the minimal amount of $\mathrm{FeCl}_{3}$ necessary to promote the reaction under sonication was screened. The results are described on Table 2. Smaller amounts of catalyst favored the formation of $\beta$-hydroxy-sulfone (4a, Table 2, entries 1-3), however, an improvement in both conversion and selectivity was observed when the amount of $\mathrm{FeCl}_{3}$ was increased to 20 and $30 \mathrm{~mol} \%$ with no significant changes in the product ratio (Table 2, entries 4 and 5). Nonetheless, the increment in the amount of $\mathrm{FeCl}_{3}$ to $40 \mathrm{~mol} \%$ led to a decrease in both conversion and selectivity due to the formation of several by-products in the reaction (Table 2, entry 6). Therefore, the control of the amount of $\mathrm{FeCl}_{3}$ used in the reaction is fundamental because it is directly related to the conversion and selectivity of the formed products.

As mentioned before, ultrasound irradiation can be used as a source of hydroxyl radical and other reactive oxygen species. ${ }^{16}$ The combination of ultrasound irradiation and persulfate has been proved to be effective for removing several kinds of pollutants through the generation of both $\mathrm{HO}^{\circ}$ and $\mathrm{SO}_{4}^{-}{ }^{-25}$ Thus, it would be expected that by using

Table 1. $\mathrm{FeCl}_{3}$ promoted oxysulfonylation of styrene 1a using benzenesulfinic acid sodium salt, 2a, in different solvents ${ }^{\mathrm{a}}$

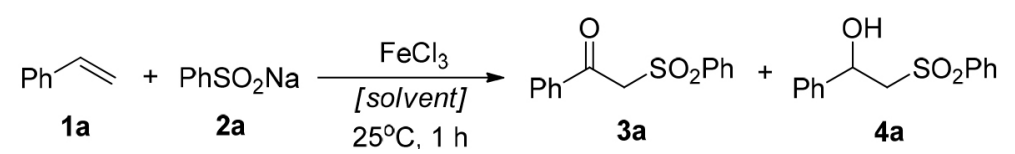

\begin{tabular}{|c|c|c|c|c|}
\hline entry & Solvent & time $/ \mathrm{h}$ & $3 \mathbf{a}^{\mathrm{b}} / \%$ & $\mathbf{4} \mathbf{a}^{\mathrm{b}} / \%$ \\
\hline 1 & $\mathrm{CH}_{2} \mathrm{Cl}_{2}$ & 24 & 39 & 30 \\
\hline 2 & $\mathrm{H}_{2} \mathrm{O}$ & 24 & 20 & 6 \\
\hline 3 & THF & 24 & 5 & - \\
\hline 4 & acetone & 24 & 67 & 18 \\
\hline 5 & $\mathrm{MeCN}$ & 24 & 53 & 27 \\
\hline $6^{c}$ & acetone & 1 & 61 & 20 \\
\hline $7^{c}$ & $\mathrm{MeCN}$ & 1 & 75 & 4 \\
\hline $8^{c}$ & $\mathrm{MeCN}: \mathrm{H}_{2} \mathrm{O}^{\mathrm{d}}$ & 1 & 82 & 6 \\
\hline
\end{tabular}

aReaction conditions: reactions were performed using $\mathbf{1 a}(0.25 \mathrm{mmol}), \mathbf{2 a}(0.375 \mathrm{mmol})$ and $\mathrm{FeCl}_{3}(20 \mathrm{~mol} \%)$ in the appropriate solvent $(3 \mathrm{~mL})$ at $25^{\circ} \mathrm{C}$; ${ }^{b}$ determined by gas chromatography (GC) analysis; ${ }^{c}$ the reaction was performed under sonication; ${ }^{\mathrm{d}} \mathrm{a}$ 2:1 mixture was used. 
Table 2. Oxysulfonylation of styrene, 1a, using benzenesulfinic acid sodium salt, 2a, using different amounts of $\mathrm{FeCl}_{3}{ }^{\mathrm{a}}$

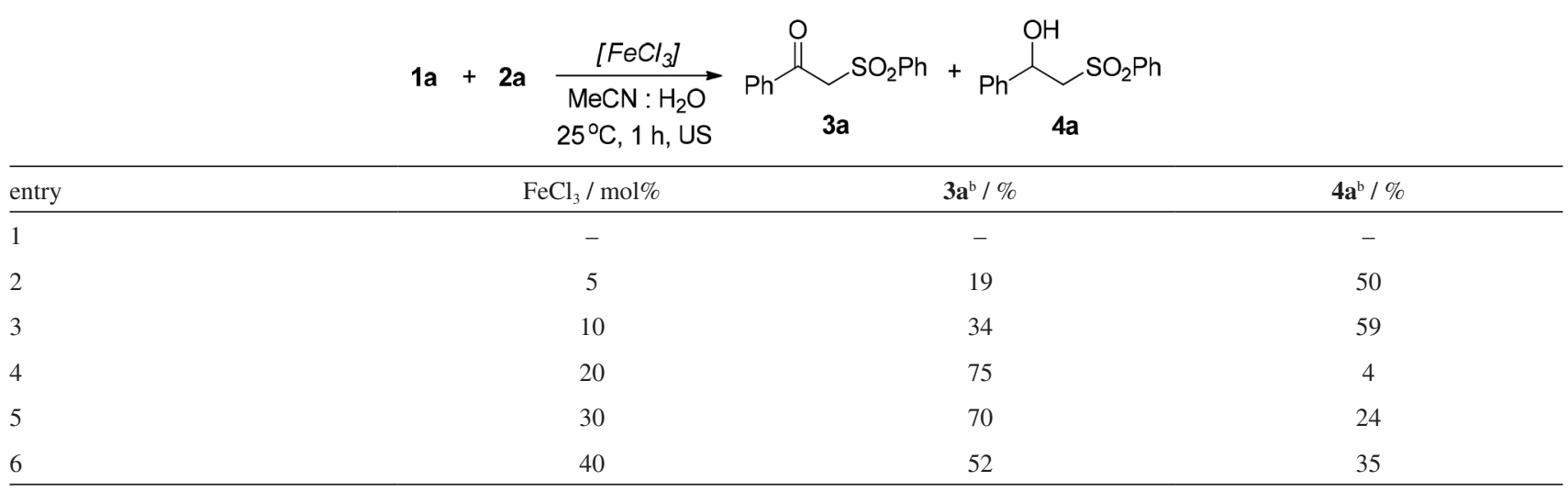

${ }^{a}$ Reaction conditions: reactions were performed using $\mathbf{1 a}(0.25 \mathrm{mmol}), \mathbf{2 a}(0.375 \mathrm{mmol})$ in $\mathrm{MeCN}: \mathrm{H}_{2} \mathrm{O}(3 \mathrm{~mL})$ at $25^{\circ} \mathrm{C}$ under sonication using the appropriate

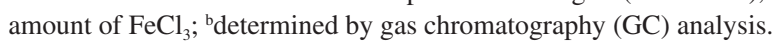

the combination of ultrasound irradiation and persulfate, an increment not only in the formation of radicals would be observed, but also in the selectivity favoring the formation of 3a. The use of a persulfate to accelerate the oxysulfonylation reaction through the formation of the sulfinyl radical was also recently described..$^{26-33}$ The results are described in Table 3.

Initially, the efficacy of the reaction was investigated using $20 \mathrm{~mol} \%$ of ammonium persulfate $\left[\left(\mathrm{NH}_{4}\right)_{2} \mathrm{~S}_{2} \mathrm{O}_{8}\right]$ as the oxidant, without $\mathrm{FeCl}_{3}$. After $1 \mathrm{~h}$, the reaction was not complete with much of the remaining starting material being observed together with a conversion of $39 \%$ to product $\mathbf{3 a}$ and only traces of $\mathbf{4 a}$ (Table 3 , entry 2 ). The best result was observed when $20 \mathrm{~mol} \%$ of $\left(\mathrm{NH}_{4}\right)_{2} \mathrm{~S}_{2} \mathrm{O}_{8}$ and $20 \mathrm{~mol} \%$ of $\mathrm{FeCl}_{3}$ were used, where excellent conversions and selectivities to the $\beta$-keto-sulfone 3a were observed after $1 \mathrm{~h}$ (Table 3, entry 3). Additional increment in the amount of oxidant to $40 \mathrm{~mol} \%$ resulted in $84 \%$ conversion to 3a (Table 3, entry 4). Noteworthy, the corresponding thiosulfonate (5) was obtained as a byproduct in the reaction in a small amount. This result was later confirmed by increasing the amount of $\left(\mathrm{NH}_{4}\right)_{2} \mathrm{~S}_{2} \mathrm{O}_{8}$ and $\mathrm{FeCl}_{3}$ to $100 \mathrm{~mol} \%$, where $\mathbf{4 a}$ was obtained as the major product in the reaction together with the corresponding thiosulfonate $\mathbf{5}$ (Table 3, entry 5). Finally, a reaction under stirring using the optimized conditions was performed in order to compare the efficacy of ultrasound in the oxysulfonylation of styrene, 1a. Using these conditions 3a was obtained as the major product after $24 \mathrm{~h}$ reaction (Table 3, entry 6 ).

The optimized reaction conditions namely: 1a (0.25 mmol), 2a (0.375 mmol), $\mathrm{FeCl}_{3}(20 \mathrm{~mol} \%)$ and $\left(\mathrm{NH}_{4}\right)_{2} \mathrm{~S}_{2} \mathrm{O}_{8}(20 \mathrm{~mol} \%)$ in $\mathrm{MeCN}: \mathrm{H}_{2} \mathrm{O}[3 \mathrm{~mL}(2: 1)]$ under sonication for $1 \mathrm{~h}$ were then applied to different substrates in order to explore the scope of the method, as well as the electronic effects of the substituents on the reaction yields. The results are described on Table 4, where it can be seen that the method was efficient for most of the substrates used.

Table 3. Oxysulfonylation of styrene, 1a, using benzenesulfinic acid sodium salt, 2a, using different amounts of $\mathrm{FeCl}_{3}$ and $\left(\mathrm{NH}_{4}\right)_{2} \mathrm{~S}_{2} \mathrm{O}_{8}{ }^{\mathrm{a}}$

\begin{tabular}{|c|c|c|c|c|c|}
\hline & $1 a+2 a$ & $\begin{array}{c}\begin{array}{l}\mathrm{FeCl}_{3} \\
{\left[\left(\mathrm{NH}_{4}\right)_{2} \mathrm{~S}_{2} \mathrm{O}_{8}\right]}\end{array} \\
\underset{\mathrm{MeCN}: \mathrm{H}_{2} \mathrm{O}}{2}\end{array}$ & $\mathrm{Ph}$ & $\begin{array}{l}\mathrm{SSO}_{2} \mathrm{Ph} \\
\mathbf{5}\end{array}$ & \\
\hline entry & $\mathrm{FeCl}_{3} / \mathrm{mol} \%$ & $\left(\mathrm{NH}_{4}\right)_{2} \mathrm{~S}_{2} \mathrm{O}_{8} / \mathrm{mol} \%$ & $3 \mathbf{a}^{\mathrm{b}} / \%$ & $4 a^{\mathrm{b}} / \%$ & $5^{\mathrm{b}} / \%$ \\
\hline 1 & 20 & - & 75 & 9 & - \\
\hline 2 & - & 20 & 39 & 2 & - \\
\hline 3 & 20 & 20 & 91 & 4 & - \\
\hline 4 & 20 & 40 & 84 & 3 & 9 \\
\hline 5 & 100 & 100 & 6 & 51 & 22 \\
\hline $6^{\mathrm{c}}$ & 20 & 20 & 80 & 10 & - \\
\hline
\end{tabular}

a Reaction conditions: reactions were performed using $\mathbf{1 a}(0.25 \mathrm{mmol}), \mathbf{2 a}(0.375 \mathrm{mmol})$ and the appropriate amount of $\mathrm{FeCl}_{3}$ and $\left(\mathrm{NH}_{4}\right)_{2} \mathrm{~S}_{2} \mathrm{O}_{8}$ in $\mathrm{MeCN}: \mathrm{H}_{2} \mathrm{O}$ $(3 \mathrm{~mL})$ at $25^{\circ} \mathrm{C}$ under sonication for $1 \mathrm{~h}$; betermined by gas chromatography $(\mathrm{GC})$ analysis; ${ }^{\mathrm{c}}$ the reaction was performed under stirring for $24 \mathrm{~h}$. 
When compounds $\mathbf{1 a}$ and $\mathbf{1 b}$ were used as substrates together with the sulfinate $\mathbf{2 a}$, the desired products were obtained in good yields, being observed better selectivities when 1a was used as substrate (Table 4, entries 1 and 2). When 1c was used, the corresponding $\beta$-hydroxysulfone $4 \mathbf{c}$ was obtained in $90 \%$ yield as the exclusive reaction product (Table 4, entry 3). The use of trans-stilbene (1d), a 1,2-disubstituted alkene, led to a complex mixture of products, and the isolation of $\mathbf{3 d}$ and $\mathbf{4 d}$ was not possible in this case (Table 4, entry 4).

The presence of deactivating groups such as the fluorine atom on the aromatic ring led preferentially to the $\beta$-keto-

Table 4. Oxysulfonylation of different alkenes promoted by ultrasound

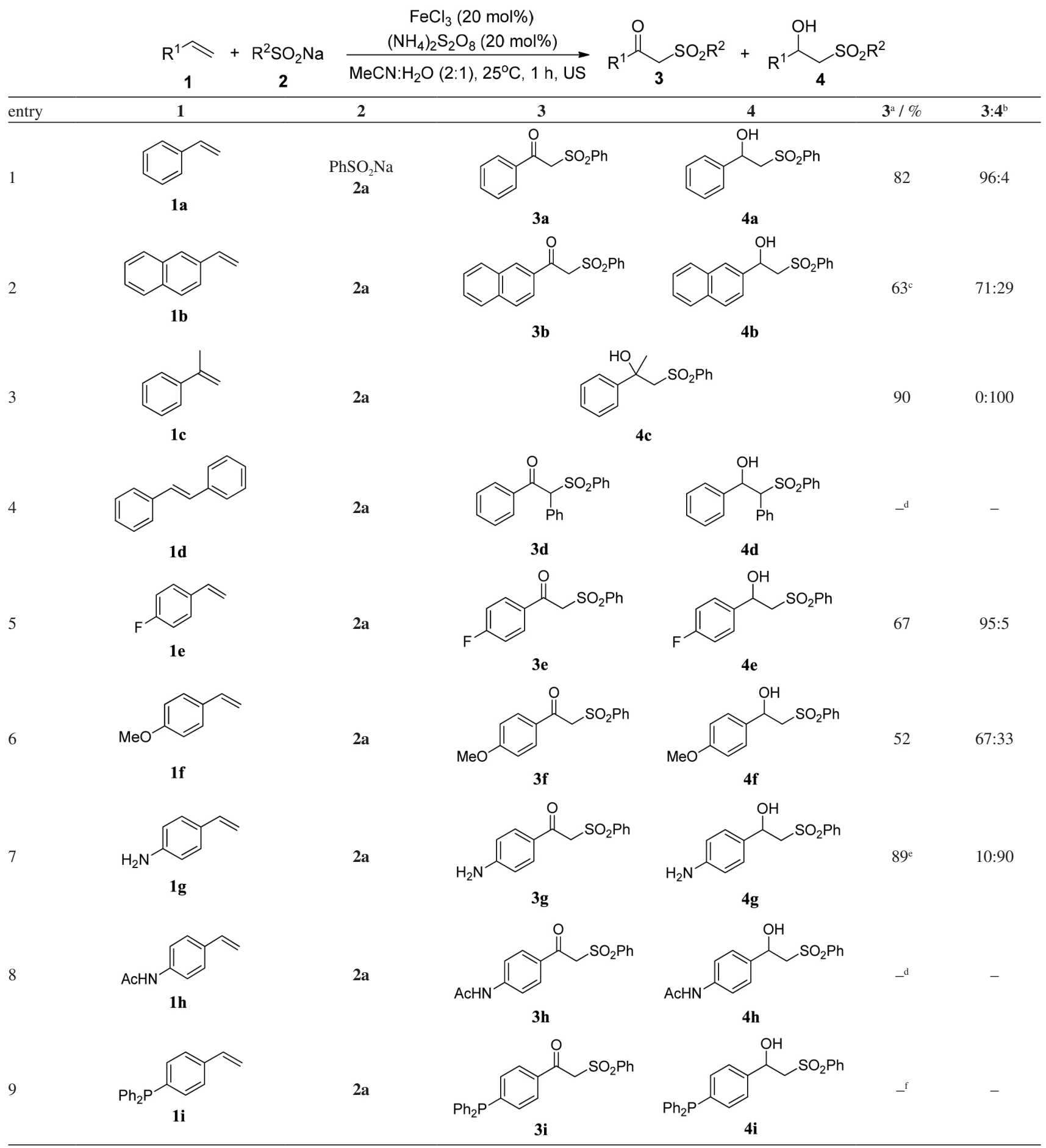


Table 4. Oxysulfonylation of different alkenes promoted by ultrasound (cont.)

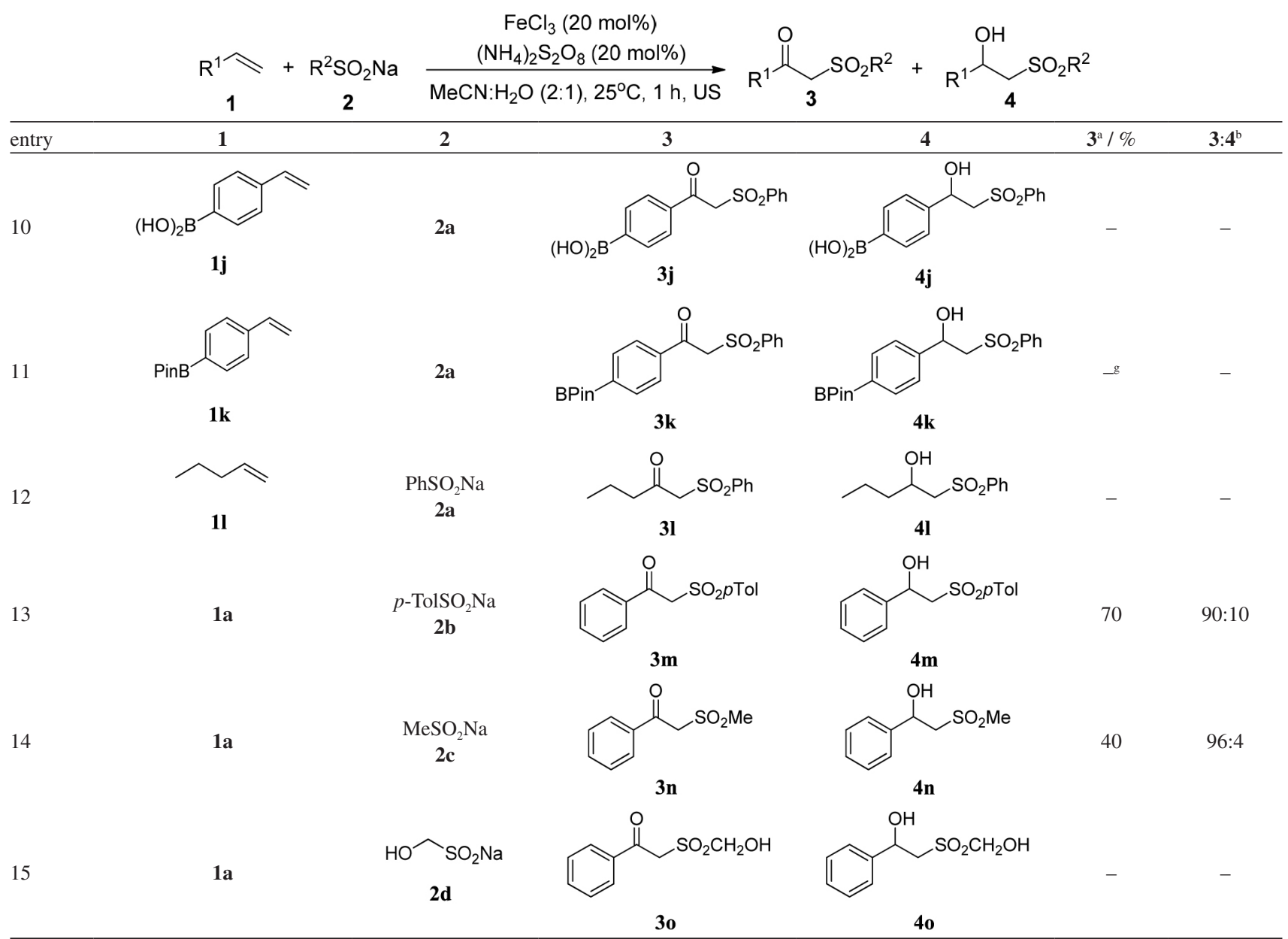

${ }^{a}$ Isolated yield; ${ }^{b}$ determined by gas chromatography (GC) analysis; ${ }^{c}$ the reaction was sonicated for $2 \mathrm{~h}$; ${ }^{\mathrm{d}}$ c complex mixture of products was obtained; ${ }^{\mathrm{e}}$ the yield refers to the mixture of compounds $\mathbf{3} \mathbf{g}$ and $\mathbf{4} \mathbf{g}$; ${ }^{\mathrm{f}}$ the corresponding phosphinoxide was obtained as product; ${ }^{\mathrm{g}}$ the corresponding boronic acid $\mathbf{1} \mathbf{j}$ was obtained as product.

sulfone (3e) in moderate yield (Table 4, entry 5). Moreover, when 4-methoxyvinylbenzene (1f) was used as substrate, a decrease in yield and in the selectivity of the reaction was observed, where the desired product $\mathbf{3 f}$ was obtained in $52 \%$ yield in a ratio of 67:33 (Table 4, entry 6). These results indicate that the electronic effects can influence both the yield and the selectivity of the reaction and that the presence of donor groups in the starting alkene would favor the formation of $\beta$-hydroxysulfone. This observation was confirmed when 4-vinylaniline (1g) was subjected to the same reaction conditions, where the corresponding products $\mathbf{3 g}$ and $\mathbf{4 g}$ were obtained in $89 \%$ yield as an inseparable mixture, being the $\beta$-hydroxysulfone $(\mathbf{4 g})$ the major product (Table 4 , entry 7 ). When amide $\mathbf{1 h}$ was used as substrate, a complex mixture of products was obtained (Table 4, entry 8). When 4-(diphenylphosphino)-styrene (1i) was used in the reaction, the expected products $\mathbf{3 i}$ and $4 \mathbf{i}$ were not observed, and the only product obtained in the reaction was the corresponding phosphinoxide (Table 4, entry 9). This fact indicated that the presence of some functionalities containing a Lewis base character in the starting material would be troublesome when performing the reaction.

A study of the behavior of the reaction in the presence of Lewis acids, such as boronic acid $\mathbf{1} \mathbf{j}$, was also performed. In this case, a complex mixture of products was observed in the reaction (Table 4, entry 10). When the corresponding boronic ester $\mathbf{1 k}$ was used in the oxysulfonylation reaction, the only product observed was the boronic acid $\mathbf{1} \mathbf{j}$, probably due to the presence of water and $\mathrm{FeCl}_{3}$ in the reaction medium (Table 4, entry 11). This result is in agreement with the literature, ${ }^{34}$ where it is described that the hydrolysis of some boron compounds can occur in the presence of $\mathrm{FeCl}_{3}$. Finally, when 1-pentene (11) was used as the substrate, the desired product $\mathbf{3 l}$ was not observed (Table 4 , entry 12 ). 
Table 5. Oxysulfonylation of styrene, 1a, using benzenesulfinic acid sodium salt, 2a, under argon atmosphere ${ }^{\mathrm{a}}$

\begin{tabular}{|c|c|c|c|}
\hline & $\begin{array}{c}\mathrm{FeCl}_{3}(20 \mathrm{~mol} \%) \\
+2 \mathrm{a} \underset{[\text { conditions] }}{\stackrel{\left(\mathrm{NH}_{4}\right)_{2} \mathrm{~S}_{2} \mathrm{O}_{8}(20 \mathrm{~mol} \%)}{\longrightarrow}}\end{array}$ & h + & \\
\hline entry & Condition & $3 \mathbf{a}^{\mathrm{b}} / \%$ & $6^{\mathrm{b}} / \%$ \\
\hline 1 & $\left.\left.\left.\mathrm{MeCN}, 25^{\circ} \mathrm{C}, 1 \mathrm{~h},\right)\right)\right), \mathrm{Ar}$ & 19 & 14 \\
\hline 2 & $\left.\left.\left.\mathrm{MeCN}, \mathrm{TEMPO}, 25^{\circ} \mathrm{C}, 1 \mathrm{~h},\right)\right)\right), \mathrm{Ar}$ & - & - \\
\hline
\end{tabular}

The use of different sodium sulfinates in the oxysulfonylation of alkenes promoted by ultrasound was also evaluated. When styrene $\mathbf{1 a}$ and sodium sulfinate $\mathbf{2 b}$ were used, similar yields and selectivities were observed (Table 4, entries 1 and 13). However, when sodium methanesulfinate 2d was used, the corresponding product $\mathbf{3 n}$ was obtained in only $40 \%$ yield with a high selectivity, favoring the $\beta$-keto-sulfone (Table 4, entry 14). Finally, when sodium hydroxymethanesulfinate $\mathbf{2 c}$ was used, the corresponding products were not observed (Table 4, entry 15).

In an attempt to obtain some information about the mechanism of the reaction, some additional experiments were performed. First, the optimized conditions were applied for the reaction of 1a and 2a under argon atmosphere using only anhydrous acetonitrile as solvent (Table 5, entry 1). In this case, 3a was obtained in a low conversion together with the corresponding vinyl sulfone, 6.

Next, the reaction was performed in presence of (2,2,6,6-tetramethylpiperidin-1-yl)oxyl (TEMPO), a radical scavenger (Table 5, entry 2). In this specific case, the desired product 3a was not observed and only the starting materials were recovered. The results described in Table 5 indicated that the presence of oxygen is important for the oxysulfonylation reaction and are in agreement with those previously described in the literature. ${ }^{16}$

Noteworthy, when the reaction was carried out using the $\beta$-hydroxysulfone $\mathbf{4 a}$ as the substrate under the optimized reaction conditions, the corresponding $\beta$-keto-sulfone $\mathbf{3 a}$ was not observed indicating that $\mathbf{4 a}$ was not the intermediate in the reaction (Scheme 1).

$$
\begin{gathered}
\mathrm{FeCl}_{3}(20 \mathrm{~mol} \%) \\
\left(\mathrm{NH}_{4}\right)_{2} \mathrm{~S}_{2} \mathrm{O}_{8}(20 \mathrm{~mol} \%) \\
\mathrm{MeCN}: \mathrm{H}_{2} \mathrm{O}(2: 1), 25^{\circ} \mathrm{C}, 1 \mathrm{~h}, \mathrm{US}
\end{gathered}
$$$$
4 a
$$

Scheme 1. Attempt to synthesize $\mathbf{3 a}$ from $\mathbf{4 a}$.

The suggested reaction mechanism was proposed by Huang and co-workers ${ }^{35}$ and Yadav and co-workers ${ }^{36}$ which is based on the generation of an oxygen-centered radical and its resonance structure sulfonyl radical A (Scheme 2). The capture of this radical by the appropriate alkene would lead to a carbon-centered radical $\mathrm{B}$, which would be trapped by $\mathrm{O}_{2}$ to give the corresponding peroxyl radical C. Further reaction with radical $\mathrm{B}$ to generate the oxyl radical $\mathrm{D}$ followed by hydrogen radical abstraction would give the $\beta$-keto sulfone (Scheme 2).

\section{Conclusions}

In summary, we have demonstrated the ultrasoundassisted oxysulfonylation of different alkenes using sodium salts of organosulfinic acids under air atmosphere in a very chemo- and regioselective way. The corresponding $\beta$-keto-sulfones were obtained in short reaction time when

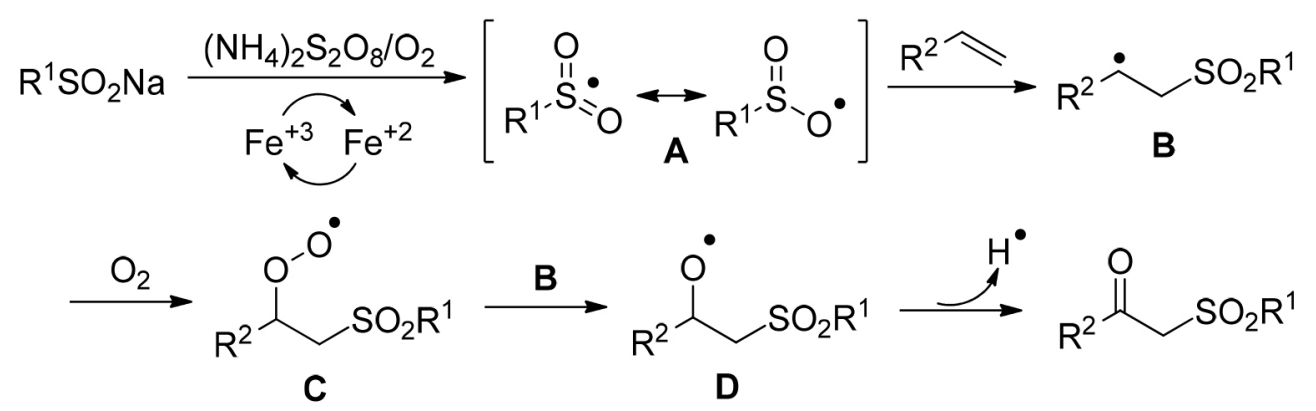

Scheme 2. Suggested mechanistic pathway. 
compared to other procedures described in the literature, high yield and purity. The method is simple, fast and general, allowing further applications in the synthesis of more complex compounds.

\section{Supplementary Information}

Additional experimental procedures and spectroscopic characterization data, as well as ${ }^{1} \mathrm{H},{ }^{13} \mathrm{C}$ and ${ }^{11} \mathrm{~B} \mathrm{NMR}$ spectra for all synthesized compounds are available free of charge at http://jbcs.sbq.org.br as PDF file.

\section{Acknowledgments}

The authors gratefully acknowledge CNPq (482299/2013-4) and CAPES for financial support. P. H. M. and Q. P. S. B. F. are also thankful to CNPq for their fellowships.

\section{References}

1. Otocka, S.; Kwiatkowska, M.; Madalińska, L.; Kielbasinski, P.; Chem. Rev. 2017, 117, 4147.

2. Markitanov, Y. M.; Timoshenko, V. M.; Shermolovich, Y. G.; J. Sulfur Chem. 2014, 35, 188.

3. Pokhodylo, N. T.; Matiychuk, V. S.; Obushak, M. D.; Synthesis 2009, 2321.

4. Wolf, W. M.; J. Mol. Struct. 1999, 474, 113.

5. Katritzky, A. R.; Abdel-Fattah, A. A. A.; Wang, M. J.; J. Org. Chem. 2003, 68, 1443.

6. Wildeman, J.; Van Leusen, A. M.; Synthesis 1979, 733.

7. Thomsen, M. W.; Handwerker, B. M.; Katz, S. A.; Belser, R. B.; J. Org. Chem. 1988, 53, 906.

8. Kreis, M.; Nieger, M.; Brase, S.; J. Organomet. Chem. 2006, $691,2171$.

9. Lai, C.; Xi, C.; Jiang, Y.; Hua, R.; Tetrahedron Lett. 2005, 46, 513.

10. Yang, F. L.; Tian, S. K.; Tetrahedron Lett. 2017, 58, 487.

11. Rong, G.; Mao, J.; Yan, H.; Zheng, Y.; Zhang, G.; J. Org. Chem. 2015, 80, 4697.

12. Singh, A. K.; Chawla, R.; Yadav, L. D. S.; Tetrahedron Lett. 2014, 55, 4742 .

13. Trost, B. M.; Angew. Chem., Int. Ed. 1995, 34, 259.
14. Trost, B. M.; Science 1991, 254, 1471.

15. Lu, Q.; Zhang, J.; Wei, F.; Qi, Y.; Wang, H.; Liu, Z.; Lei, A.; Angew. Chem., Int. Ed. 2013, 52, 7156.

16. Piera, J.; Backvall, J. E.; Angew. Chem., Int. Ed. 2008, 47, 3506.

17. Ferkous, H.; Merouani, S.; Hamdaoui, O.; Pétrier, C.; Ultrason. Sonochem. 2017, 34, 580.

18. Banerjee, B.; Ultrason. Sonochem. 2017, 35, 15.

19. Sancheti, S. V.; Gogate, P. R.; Ultrason. Sonochem. 2017, 36, 527.

20. Cintas, P.; Ultrason. Sonochem. 2016, 28, 257.

21. Perrin, D. D.; Armarego, W. L. F.; Purification of Laboratory Chemicals; Pergamon: Oxford, 1988.

22. Oliveira, R. A.; Silva, R. O.; Molander, G. A.; Menezes, P. H.; Magn. Reson. Chem. 2009, 47, 873.

23. Wei, W.; Liu, C.; Yang, D.; Wen, J.; You, J.; Suo, Y.; Wang, H.; Chem. Commun. 2013, 49, 10234.

24. Pagire, S. K.; Paria, S.; Reiser, O.; Org. Lett. 2016, 18, 2106.

25. Chawla, R.; Singh, A. K.; Yadav, L. D. S.; Eur. J. Org. Chem. 2014, 2032.

26. Wang, X.; Wang, L.; Li, J.; Qiu, J.; Cai, C.; Zhang, H.; Sep. Purif. Technol. 2014, 122, 41.

27. Darsinou, B.; Frontistis, Z.; Antonopoulou, M.; Konstantinou, I.; Mantzavinos, D.; Chem. Eng. J. 2015, 280, 623.

28. Li, B.; Li, L.; Lin, K.; Zhang, W.; Lu, S.; Luo, Q.; Ultrason. Sonochem. 2013, 20, 855.

29. Li, B.; Zhu, J.; Chem. Eng. J. 2016, 284, 750.

30. Chen, W. S.; Su, Y. C.; Ultrason. Sonochem. 2012, 19, 921.

31. Neppolian, B.; Doronila, A.; Ashokkumar, M.; Water Res. 2010, 44, 3687.

32. Yang, Q.; Zhong, Y.; Zhong, H.; Li, X.; Du, W.; Li, X.; Chen, R.; Zeng, G.; Process Saf. Environ. Prot. 2015, 98, 268.

33. Wang, S.; Zhou, N.; Wu, S.; Zhang, Q.; Yang, Z.; Ultrason. Sonochem. 2015, 23, 128.

34. Blevins, D. W.; Yao, M. L.; Yong, L.; Kabalka, G. W.; Tetrahedron Lett. 2011, 52, 6534.

35. Shi, X.; Ren, X.; Ren, Z.; Li, J.; Wang, Y.; Yang, S.; Gu, J.; Gao, Q.; Huang, G.; Eur. J. Org. Chem. 2014, 5083.

36. Singh, A. K.; Chawla, R.; Yadav, L. D. S.; Tetrahedron Lett. 2014, 55, 2845.

Submitted: January 30, 2018 Published online: April 10, 2018 